THE LANGUAGE OF HISTORY 



\section{The Language of History}

SANSKRIT NARRATIVES OF

INDO-MUSLIM RULE

Audrey Truschke

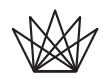

Columbia University Press

New York 


\section{Columbia University Press}

Publishers Since 1893

New York Chichester, West Sussex

cup.columbia.edu

Copyright (C) 202I Columbia University Press

All rights reserved

Library of Congress Cataloging-in-Publication Data

Names: Truschke, Audrey, author.

Title: The language of history : Sanskrit narratives of Indo-Muslim rule / Audrey Truschke.

Description: New York : Columbia University Press, [202I] |

Includes bibliographical references and index.

Identifiers: LCCN 2020021927 (print) | LCCN 2020021928 (ebook) |

ISBN 9780231197045 (hardback) | ISBN 9780231197052 (trade paperback) |

ISBN 9780231551953 (ebook)

Subjects: LCSH: India—Civilization-Islamic influences—Sources. |

India-Civilization-I200-I765-Sources. | India-History-Sources. |

India—Historiography. | Sanskrit language-History. | Sanskrit literature-History

and criticism. | Literature and history-India. | Muslims—India—History—Sources. |

$$
\text { Islam-India-History-Sources. }
$$

Classification: LCC DS427.T78 202 I (print) | LCC DS427 (ebook) | DDC 954.02072-dc23

LC record available at https://lccn.loc.gov/2020021927

LC ebook record available at https://lccn.loc.gov/2020021928

Columbia University Press books are printed on permanent and durable acid-free paper.

Printed in the United States of America

Cover image: Madhuravijaya of Gangadevi, Punjab University Library, Lahore, ms. no. 8579

Cover design: Chang Jae Lee 
For Allison Busch,

a mentor, role model, inspiration, and friend, always 

بول، كَ سج زنده بـ اب تك كه كه

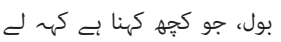

Speak, the truth is still alive;

Speak: say what you have to say.

-FAIZ AHMAD FAIZ, TRANSLATED BY YASMIN HOSAIN 
